\title{
Characterization of soil properties of Nothofagus spp. forest with and without scarification in the Andean region of Southern Chile
}

\author{
J. Reyes ${ }^{1,2}$, O. Thiers ${ }^{1,2^{*}}$, V. Gerding ${ }^{1,2}$ \\ ${ }^{1}$ Universidad Austral de Chile, Facultad de Ciencias Forestales y Recursos Naturales. C. P. 5090000. Valdivia, Chile. ${ }^{2}$ Universidad \\ Austral de Chile, Centro de Investigación en Suelos Volcánicos-CISVo. C. P. 5090000. Valdivia, Chile. "Corresponding author: \\ othiers@uach.cl
}

\begin{abstract}
Soil scarification has been used as a silvicultural method to eliminate competition in tree regeneration, but it modifies soil characteristics. In order to evaluate soil changes due to silvicultural management, we characterized a volcanic soil subjected to a mechanized scarification in a Nothofagus spp. forest in the Andean region of southern Chile ( $39^{\circ} 54^{\prime} \mathrm{S}, 71^{\circ} 56^{\prime} \mathrm{W} ; 970 \mathrm{~m}$ asl). Scarification removed between 20 and $40 \mathrm{~cm}$ of topsoil in forest gaps. Two scarified areas were selected in different periods and in an undisturbed forest area. Physical properties (bulk density, penetration resistance, porosity, texture) and chemical ( $\mathrm{pH}$, soil organic matter, total- $\mathrm{N}, \mathrm{P}-\mathrm{Olsen}, \mathrm{K}, \mathrm{Mg}$ and $\mathrm{Ca}$ extractable, $\mathrm{Al}$ saturation) were analyzed in both the scarified soil and undisturbed forest. The morphology of the soil was a result of the formation of a stratified soil. Bulk density was higher in the superficial layer of the scarified soil $\left(0.9\right.$ to $\left.1.2 \mathrm{~g} \mathrm{~cm}^{-3}\right)$ when compared to the undisturbed forest $\left(0.3 \mathrm{~g} \mathrm{~cm}^{-3}\right)$. With regards to the undisturbed forest, soil scarification exposed a superficial soil of coarser texture, lower total porosity (50-60\% vs. $80 \%$ ) and it decreased the soil nutrient supply. There were no large variations in soil properties when comparing the oldest scarified soil with the most recent one. There were important changes in morphology, physical and chemical properties of the scarified soil.
\end{abstract}

Keywords: Soil morphology, texture, fertility, Nothofagus forests, silviculture 


\section{Introduction}

Nothofagus spp. forests of the Andean region of southern Chile have a high productive potential but historically they were subjected to an indiscriminate explotation, which caused their degradation (Donoso and Lara, 1996). Therefore, it is necessary to study options for the recovery of degraded areas aiming to facilitate the formation of new forests under an appropriate silvicultural system. Silvicultural management in native forests of Chile does not consider the effect on the soil, although there are studies linking the effect of soil fertility to forest productivity. Gerding and Thiers (2002) evaluated soil fertility in native forests of Nothofagus betuloides (Mirb) Blume in Tierra del Fuego, founding poor soils (shallow, high stoniness, poor drainage, high acidity and low available water capacity among others), and on them, low-productivity forests; while Thiers (2004) observed forests of Nothofagus obliqua (Mirb) Oerst with good productivity between Maule and Los Lagos Regions, associated to good fertility soils (high depth, low bulk density, high organic matter and high available water capacity).

Soil scarification is a practice used to regenerate forests, especially in the logged forest areas or after silvicultural intervention. It is accomplished by plowing the soil in the superficial horizons or removing a superficial layer of soil and litter, in order to reduce competition and release resources (light, space, water and nutrients) in favor of the regeneration -natural or artificial regeneration- of interest forest species (Resco de Dios et al., 2005., Aoyama et al., 2009). It eliminates or mitigates competition with other species and exposes the mineral soil, which is usually covered by a litter thick in colder climates (it has been commonly used in boreal or low temperature forests). However, this method decreases soil fertility (Zaczek, 2002; Resco de Dios et al., 2005; Gastadello et al. 2007; Hope, 2007). In the case of Chilean species, scarification favors the establishment of Nothofagus species, which have catastrophic regeneration mode, since they establish themselves after disturbances such as landslides and volcanic eruptions in the Andes area (Veblen and Ashton, 1978; Veblen et al., 1996).

This study evaluated a scarification after a shelterwood cutting carried out in a Nothofagus spp. forest located in the Cordillera de Los Andes of southern Chile, with the aim of providing information about the condition of the soil during pre-and post-intervention, in an area that lacks information about its soil. This information should be considered in the silvicultural management that is or could be performed as part of the activities for the recovery of the native forest, currently being promoted by the state of Chile (Ministerio de Agricultura, 2008).

The objectives are to characterize the soil in a Nothofagus spp. forest in gaps subjected to scarification and to compare these conditions with those of the original undisturbed forest, and to quantify the amount of nutrients removed as a consequence of scarification.

\section{Materials and Methods}

\subsection{Study area}

The study was conducted at the Pilmaiquén farm, Piedras Negras site ( $39^{\circ} 54^{\prime} 42,44$ " S, $71^{\circ} 56^{\prime}$ 5,67" W, elevation $970 \mathrm{~m}$ asl) in the Andes, southern Chile. The place is located on the slopes of the MochoChoshuenco volcano, whose activity has deposited mainly basaltic material (Gonzalez-Ferrán, 1995). The climate is Andean Polar, typical of high mountains outside the tropics, and its agroclimate is defined as Central Cordillera (INIA, 1989). The average annual temperature is $11{ }^{\circ} \mathrm{C}$, reachig $5{ }^{\circ} \mathrm{C}$ during the coldest month (August) and $16{ }^{\circ} \mathrm{C}$ during the warmest month (February); the absolute minimum temperature can drop below $-5 \mathrm{C}^{\circ}$ in the coldest period, while the absolute maximum can reach above $30{ }^{\circ} \mathrm{C}$ in the warmest period. Rainfall is approximately $3,000-3,500$ $\mathrm{mm}$ per year and during the winter period, turning into 
snow at the level of $800 \mathrm{~m}$ asl. The soil has transition features between the Liquiñe series, which is member of the medial over sandy family, mesic of the Acrudoxic Hapludands, and the Choshuenco series, member of the coarse loamy family, mixed, mesic of the Andic Dystrudepts (CIREN, 2001).

During the summer 2006-2007, a regeneration cutting was carried out using the shelterwood cutting method (Nyland, 2002., Röhrig et al., 2006) in a coihueraulí-tepa type forest (Donoso, 1981), leaving clear gaps of different sizes (old gaps). After the cutting, a mechanized scarification was performed (Bulldozer Komatsu D4 with front end loader) in some of these areas, leaving others without scarifying. Unscarified areas were densely populated with the bamboo Chusquea culeou E. Desv. which completely inhibited tree regeneration. Therefore, those areas underwent scarification (new gaps) in March 2010. Approximately a layer of $20-30 \mathrm{~cm}$ was removed in the old gap and about $40 \mathrm{~cm}$ in the new gap, and a litter layer of $8 \pm$ $1 \mathrm{~cm}$ thick were removed through scarification in all the gaps, moved away and left on the periphery of the scarified area.

\subsection{Morphological and physical analysis of the soil}

In April 2011, three soil profiles were morphologically characterized according Schlatter et al. (2003) in two gaps subjected to scarification in different periods (2007: old gap and 2010: new gap; with an area of $400 \mathrm{~m}^{2}$ and $750 \mathrm{~m}^{2}$, respectively) and the undisturbed forest. The areas were separated by approximately $100 \mathrm{~m}$ and were located on a high hill, with northern exposure and slope $<10 \%$.

Undisturbed soil samples from each horizon were extracted from the profiles using $100 \mathrm{~cm}^{3}$ cylinders to determine bulk density. Four repetitions were obtained from the upper horizon of each profile and one sample was taken from each one of the lower horizons. These samples also served to determine the particle density and total porosity (Hartge and Horn, 1992). Disturbed soil samples were taken from each horizon and a granulometry analysis was performed according to Forsythe (1975), after destroying the organic matter. These measurements allowed to build volumetric depth profiles, considering an particle density of 1.2 $\mathrm{g} \mathrm{cm}^{-3}$ for organic matter (Hartge and Horn, 1992). Additionally, soil penetration resistance was measured in situ using a pocket penetrometer (Soil-Test Model CL-700), using 10 replicates per horizon, perpendicular to the profiles; the water content was not considered because has little influence on sandy soils (Henderson et al., 1988). Also, the available water capacity of the soil (water that is held with strength between $333 \mathrm{hPa}$ and $15,000 \mathrm{hPa}$ ) was estimated according to Schlatter et al. (2003).

\subsection{Chemical analysis of the soil}

Horizon samples were taken from each profile for chemical analysis, with four replicates of the superficial horizon in each profile. Also, forest litter samples were taken from a plot of $0.1 \mathrm{~m}^{2}$, with three replicates, and they were split into fine $(<2 \mathrm{~mm})$, medium $(2-5 \mathrm{~mm})$ and coarse $(>5 \mathrm{~mm})$ fractions. The soil chemical analysis was performed using the following techniques (Sadzawka et al., 2006): $\mathrm{pH}$ in distilled water and in a $0.1 \mathrm{~N} \mathrm{KCl}$ solution with a rate soil: solution $=1: 2.5$; phosphorus through Olsen extract; potassium, calcium, magnesium, iron, manganese, copper, zinc and aluminum (removable) in ammonium acetate extract at $\mathrm{pH}$ 4.8-DTPA; total carbon through oxidation with sodium dichromate and sulfuric acid; total nitrogen through Kjeldahl digestion; sulfur through calcium phosphate extract; exchangeable aluminum through $1 \mathrm{M} \mathrm{KCl}$ extract; and boron through $0.15 \% \mathrm{CaCl}_{2}$ extract at boil for 5 minutes. For the chemical analysis of the litter, this was calcinated at $500{ }^{\circ} \mathrm{C}$ for 7 hours and subsequent extraction with $10 \% \mathrm{HCl}$ for macro and microelements was carried out, and a Kjeldahl extraction was performed for total nitrogen (Sadzawka et al., 2007). These determinations and bulk density allowed calculating the amounts of nutrients present in the soil and litter. The ash content of the finer fraction of the litter was not taken into consideration as it is considered part of the mineral soil. 


\subsection{Statistical analysis}

The statistical analysis considered the description of each situation through dispersion measures, variation ranges and mean comparisons (Zar, 2010). An one-way ANOVA $(p<0.05)$ was carried out to compare only the superficial horizons of each profile, considering carbon, nitrogen, phosphorus, potassium, calcium, magnesium, sodium and aluminum, and also for bulk density and soil penetration resistance. The analysis was mainly focused on the comparison of the topsoil; because we want observe the condition of substrate for the regeneration under these three conditions. Additionally, correlation analysis (Pearson correlation coefficient, $p<0.01$ ) were performed between the variables to observe the relationships between soil properties and organic matter.

\section{Results}

\subsection{Morphology and physical properties of soil}

In all three situations it was possible to observe stratified and very deep soils (Table 1, Figures 1 and 2). They showed friable moist consistency throughout the entire profile and their color was very dark gray (10YR 3/1 and 2.5YR 3/1). The fine root content of the undisturbed forest was very abundant at the surface and decreasing with depth, the same trend was observed in the gaps, however, the new gap had a mild content area in the surface and increased between 40-100 cm deep. The level of available water was high at $1 \mathrm{~m}$ depth in the three profiles (150-200 mm) (Table 1).

The undisturbed forest soil presented a volcanic ash layer of 0-20 cm with a high content of silt (45\%). This material was removed from the scarified profiles, leaving a superficial layer of coarser granulometry ( $>$ $50 \mu \mathrm{m}$ ), particularly in the new gap (Figure 3 ). The particle size varied along the profiles, although the trend indicated a soil with predominant coarse material $(>$ $60 \%$ sand).
There was a higher soil bulk density $(p<0.05)$ in the superficial horizons of gaps (AC: $0-15 \mathrm{~cm}$ of old gap and C: $0-20 \mathrm{~cm}$ of new gap) when compared to A horizon $(0-20 \mathrm{~cm})$ of the undisturbed forest (Table 1). The values in scarified soils ranged from 0.9 to $1.2 \mathrm{~g} \mathrm{~cm}^{-3}$ within the profile. Resistance to penetration mantains similar levels in the profiles (0.5-1.0 MPa), except for the A horizon in the undisturbed forest where it was lower $(0.4 \pm 0.2 \mathrm{MPa})$, and under $1 \mathrm{~m}$ of depth, where it was higher $(1.9 \pm 0.4 \mathrm{MPa})$. The volumetric profiles (Fgure 3) showed differences in the distribution of the components between profiles and horizons. The percentage of total porosity in horizon A of the undisturbed forest was high (84\%), being lower in the AC horizon of the old clear $(67 \%)$ and in the $\mathrm{C}$ horizon of the new gap (60\%). Considering these results and the characteristics of the undisturbed forest soil, was confirmed that a layer of about $40 \mathrm{~cm}$ soil was removed in the new gap and a layer of $20-30 \mathrm{~cm}$ in the old gap.

\subsection{Soil chemical properties}

There was a higher content of organic matter $(p<$ $0.05)$ in the A horizon of the undisturbed forest $(27 \%)$ when compared to the topsoil $(7 \%)$ of scarified gaps. In depth, organic matter content tended to decrease although in some deeper $\mathrm{C}$ horizons $(95-150 \mathrm{~cm})$ of the new gap and the $4 \mathrm{C}$ horizon $(38-60 \mathrm{~cm})$ of the old gap a higher content was found when compared to superficial horizons. The soils had a strongly acidic $\mathrm{pH}$, ranging betwen 5.1-5.5, although it was moderately acidic in the topsoil of scarified gaps (Table 3), with no significant differences with the A horizon of the undisturbed forest $(p>0.05)$.

There was a higher nutrient supply of macro elements (potassium, magnesium and calcium) in the A horizon of the undisturbed forest compared with the superficial horizons of scarified gaps $(p<0.05)$ (Table 2). The sum of bases showed high levels only in the A horizon of the undisturbed forest (Table 3) and it was low in the rest of the profile, and in both scarified gaps. 
Table 1. Morphological characteristics in the profiles.

\begin{tabular}{|c|c|c|c|c|c|c|c|c|}
\hline Horizon & $\begin{array}{l}\text { Depth } \\
(\mathrm{cm})\end{array}$ & $\begin{array}{c}\text { Bulk density } \\
\left(\mathrm{g} \mathrm{cm}^{-3}\right)\end{array}$ & $\begin{array}{l}\text { Soil resistance } \\
\text { penetration } \\
(\mathrm{MPa})\end{array}$ & Consistence & Texture & Structure & Color & $\begin{array}{c}\text { Available } \\
\text { water capacity } \\
(\mathrm{mm})\end{array}$ \\
\hline \multicolumn{9}{|l|}{$\begin{array}{l}\text { Undisturbed } \\
\text { forest }\end{array}$} \\
\hline $\mathrm{A}$ & $0-20$ & $0.33 \pm 0.06 b$ & $0.4 \pm 0.2 \mathrm{~b}$ & Friable & Sandy loam & Massive & 10 YR 3/1 & 31 \\
\hline $\mathrm{AC}$ & $20-37$ & 0.83 & $0.9 \pm 0.5$ & Friable & Sandy loam & Massive & $10 \mathrm{YR} 3 / 1$ & 29 \\
\hline $2 \mathrm{C}$ & $37-50$ & 0.76 & $0.8 \pm 0.3$ & Friable & Loamy sand & Massive & $2.5 \mathrm{Y} 3 / 1$ & 32 \\
\hline $3 \mathrm{C}$ & $50-62$ & 1.05 & $0.9 \pm 0.4$ & Friable & Loamy sand & Massive & $2.5 \mathrm{Y} 3 / 1$ & 27 \\
\hline $4 \mathrm{C}$ & $62-122$ & 0.92 & $0.7 \pm 0.4$ & Friable & Loamy sand & Massive & $2.5 \mathrm{Y} 3 / 1$ & 57 \\
\hline $5 \mathrm{C}$ & $122-137+$ & 1.02 & $1.9 \pm 0.4$ & Friable & Sandy loam & Massive & $10 \mathrm{YR} 3 / 1$ & 28 \\
\hline \multicolumn{9}{|l|}{ Old gap } \\
\hline $\mathrm{AC}$ & $0-15$ & $0.81 \pm 0.13 \mathrm{a}$ & $0.9 \pm 0.6 \mathrm{a}$ & Friable & Sandy loam & Massive & 10 YR 3/1 & 34 \\
\hline $2 \mathrm{C}$ & $15-26$ & 1.14 & $1.0 \pm 0.3$ & Friable to firm & Sandy loam & Massive & $10 \mathrm{YR} 3 / 1$ & 26 \\
\hline $3 \mathrm{C}$ & $26-38$ & 1.08 & $0.5 \pm 0.4$ & Friable & Loamy sand & Single-grain & 2.5 Y $3 / 1$ & 27 \\
\hline $4 \mathrm{C}$ & $38-60$ & 0.91 & $0.8 \pm 0.4$ & Friable & Loamy sand & Massive & 2.5 Y $3 / 1$ & 46 \\
\hline $5 \mathrm{C}$ & $60-104$ & 1.15 & $1.1 \pm 0.5$ & Friable & Loamy sand & Massive & 2.5 Y $3 / 1$ & 45 \\
\hline $6 \mathrm{C}$ & $104-140$ & 1.01 & $0.8 \pm 0.3$ & Friable & Sandy loam & Massive & $10 \mathrm{YR} 3 / 1$ & 62 \\
\hline \multicolumn{9}{|l|}{ New gap } \\
\hline $\mathrm{C}$ & $0-15$ & $0.95 \pm 0.12 \mathrm{a}$ & $0.8 \pm 0.3 \mathrm{a}$ & Friable & Loamy sand & $\begin{array}{l}\text { Massive and } \\
\text { single-grain }\end{array}$ & $2.5 \mathrm{Y} 3 / 1$ & 31 \\
\hline $2 \mathrm{C}$ & $15-40$ & 1.10 & $0.8 \pm 0.5$ & Friable & Loamy sand & $\begin{array}{l}\text { Massive and } \\
\text { single-grain }\end{array}$ & 2.5 Y $3 / 1$ & 27 \\
\hline $3 \mathrm{C}$ & $40-57$ & 1.15 & $0.6 \pm 0.4$ & Friable & Loamy sand & $\begin{array}{l}\text { Massive and } \\
\text { single-grain }\end{array}$ & $2.5 \mathrm{Y} 3 / 1$ & 19 \\
\hline $4 C$ & $57-95$ & 1.10 & $0.7 \pm 0.3$ & Friable & Sandy loam & Massive & $10 \mathrm{YR} 3 / 1$ & 75 \\
\hline $5 \mathrm{C}$ & $95-150$ & 0.96 & $0.7 \pm 0.4$ & Friable & Sandy loam & Massive & 10 YR $3 / 1$ & 119 \\
\hline
\end{tabular}

Values with the same letter do not differ significantly $(p<0.05)$ between profiles to the first horizons. Values in first horizon of bulk density are mean \pm standard deviation and only mean in the others horizons; in soil resistance penetration the values are mean \pm standard deviation in all horizons.

The microelements most affected by scarification were zinc and boron (Table 3). Chemical and nutritional levels decreased with depth in all three situations, presenting low levels in general.

The removable aluminum differed between the three surface horizons $(p<0.05)$. It reached a high level in the AC horizon of the old gap, an average level in the $\mathrm{C}$ horizon of the new gap and a low level in the A horizon of the undisturbed forest (Table 2). The removable aluminum content was lower in depth, reaching medium to low levels in the three profiles. The aluminum saturation presented, in general, high levels and it was low only in the A horizon of the undisturbed forest (Table 3). The content of organic matter showed a high positive correlation $(p<0.01)$ with the levels of calcium $(\mathrm{r}=0.78)$, magnesium $(\mathrm{r}=0.82)$, phosphorus $(\mathrm{r}=0.70)$, iron $(\mathrm{r}=0.88)$, manganese $(r=0.83)$ and boron $(r=0.94)$. There was no significant correlation $(p>0.05)$ with the other elements (potassium, sodium, copper, zinc and aluminum). In turn, it correlated $(p<0.01)$ positively with total pore volume $(r=0.73)$ and inversely with bulk density $(\mathrm{r}=-0.80)$.

The amounts of nutrients contained in the first $40 \mathrm{~cm}$ of the three profiles (Table 4), had lower differences than the concentrations (Table 2). 


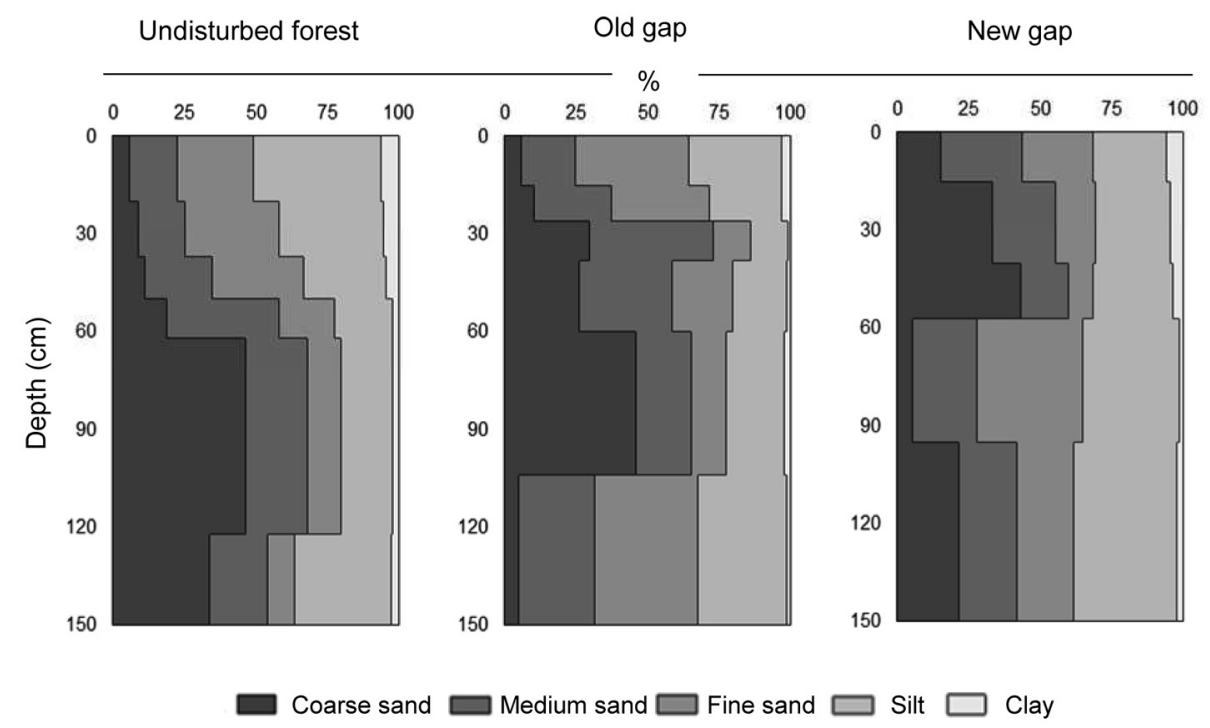

Figure 1. Granulometric profiles in gaps and undisturbed forest.

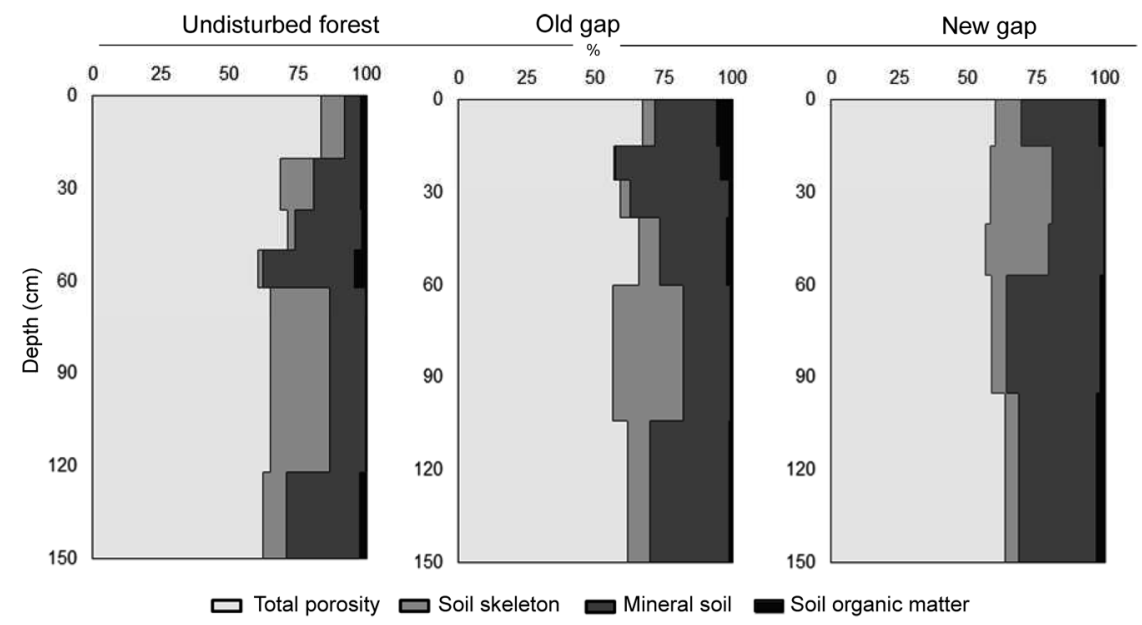

Figure 2. Volumetric profiles in gaps and undisturbed forest. 


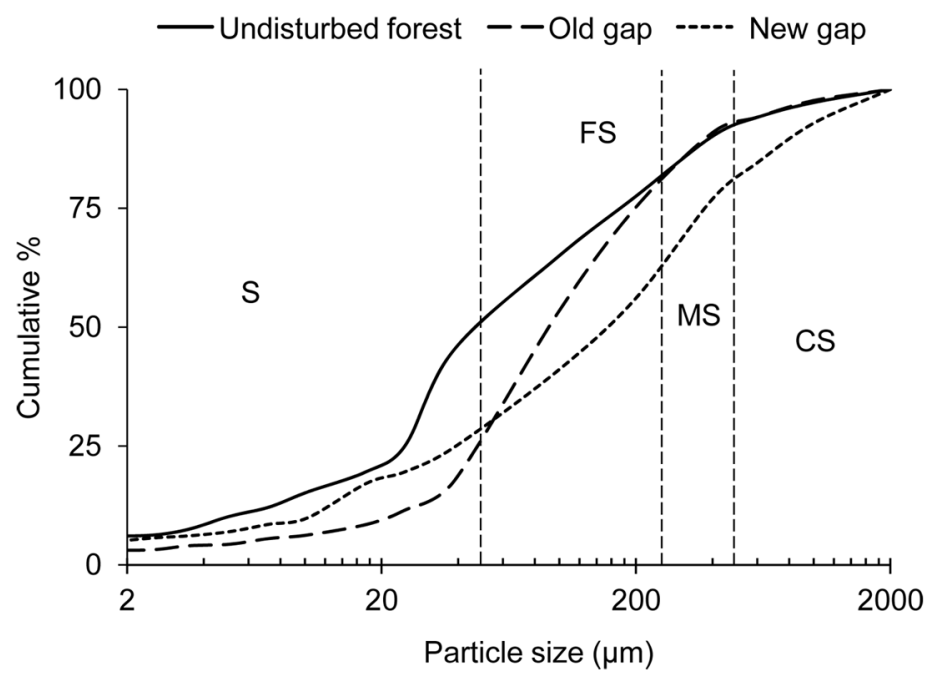

Figure 3. Textural accumulation curve for the first $20 \mathrm{~cm}$ of soil for each situation. S: silt; FS: fine sand; MS: medium sand; CS: coarse sand.

The amount of total carbon was similar in the undisturbed forest and the old gap, but it was lower in the new gap; the amounts of total nitrogen and available phosphorus were similar in the three situations. Instead, they had lower amounts of calcium, magnesium and potassium in the gaps when compared to the undisturbed forest.

On the other hand, the forest litter is Moder Mulliforme type (high presence from medium material, more similar to a Mull litter, Schlatter et al., 2003); wich presents an Oi horizon of $3 \mathrm{~cm}$, an Oe Horizon of 4 $\mathrm{cm}$ and an Oa horizon of $2 \mathrm{~cm}$. This litter showed high reserves of nitrogen and calcium (Table 5), accumulating the largest quantities in the fine and medium fractions.

\section{Discussion}

The soil of new and old gaps had similar physicochemical properties; due to three years is too short time to observe significant differences. Possibly, the amount of material removed in the old gap was minor, considering the presence of an $\mathrm{AC}$ horizon, but it also reflects a natural variation, since the material deposits by volcanic activity are not homogeneous in this area. But overall, the old gap presents a similar condition with the new gap, so the differences observed in this study has more related with the comparison between scarified or not scarified areas. Over time, the condition of scarified soils can be improved, but should be considered the change from fine to coarse topsoil substrate, so the properties of scarified gaps will be not equal to the undisturbed forest. Jiménez et al. (2008) yet after 25 years, found differences between scarified area and the original situation in a loamy spodosol. 
Table 2. Chemical analysis to profiles and horizons to soil organic matter, total carbon and nitrogen total; phosphorus Olsen, potassium, calcium, magnesium, sodium and extractable aluminum.

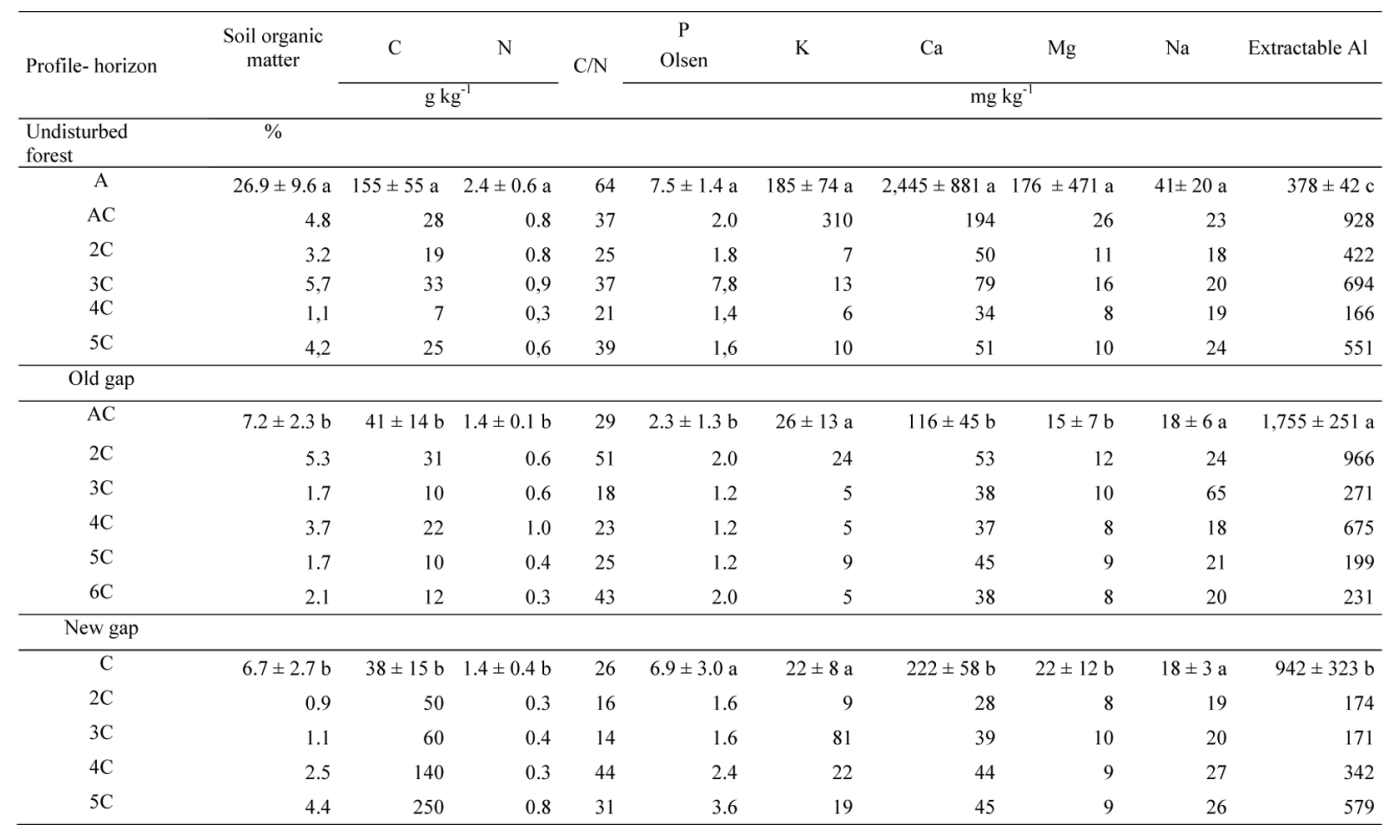

Values with the same letter do not differ significantly $(p<0.05)$ between profiles to the first horizons. Values in first horizon are mean \pm standard deviation and only mean in the others.

Soil scarification, as expected, causes changes in soil morphology. In the case of a stratified soil, the removal of the organic matter-rich top layer might expose soils that are different from the removed one. The variation between the horizons of granulometric profiles indicates the presence of several layers corresponding to deposits from different volcanic activities (GonzálezFerrán, 1995). It must be noted the presence of buried horizons containing more organic matter than more superficial horizons, which in the long term will be reached by the roots of mature trees.

The removal of topsoil in the gaps leaves a coarse textured soil (predominance of particles $>50 \mu \mathrm{m}$ ) on the surface, in contrast to the undisturbed forest which has a superficial layer of volcanic ash that is high in silt and organic matter (Figure 1). 
Table 3. Chemical analysis to profile and horizon for: $\mathrm{pH}$; iron, manganese, cooper, zinc, sulfur, boron; exchangeable aluminum, bases sum and aluminum saturation.

\begin{tabular}{|c|c|c|c|c|c|c|c|c|c|c|c|}
\hline \multirow[t]{2}{*}{ Profile- horizon } & \multirow{2}{*}{$\begin{array}{c}\mathrm{pH} \\
\mathrm{H}_{2} \mathrm{O}\end{array}$} & \multirow{2}{*}{$\begin{array}{c}\mathrm{pH} \\
\mathrm{KCl}\end{array}$} & $\mathrm{Fe}$ & Mn & $\mathrm{Cu}$ & $\mathrm{Zn}$ & $\mathrm{S}$ & B & $\begin{array}{c}\text { Exchangeable } \\
\mathrm{Al}\end{array}$ & Sum of basis & Al saturation \\
\hline & & & \multicolumn{6}{|c|}{$m g \mathrm{~kg}^{-1}$} & \multicolumn{2}{|c|}{$\mathrm{cmol}+\mathrm{kg}^{-1}$} & $\%$ \\
\hline \multicolumn{12}{|l|}{ Undisturbed forest } \\
\hline $\mathrm{A}$ & $5.5 \pm 0.2 \mathrm{a}$ & $4.6 \pm 0.3 \mathrm{a}$ & 530 & 83 & 7 & 4.8 & 10.2 & 1.1 & $0.18 \pm 0.1 \mathrm{a}$ & $14.4 \pm 4.9 \mathrm{a}$ & $1,5 \pm 0,4 \mathrm{~b}$ \\
\hline $\mathrm{AC}$ & 5.6 & 4.7 & 128 & 10 & 5 & 1.2 & 9.1 & 0.5 & 0.50 & 2.07 & 19 \\
\hline $2 \mathrm{C}$ & 5.5 & 4.7 & 43 & 6 & 5 & 0.5 & 9.1 & 0.4 & 0.32 & 0.44 & 42 \\
\hline $3 \mathrm{C}$ & 5.4 & 4.6 & 113 & 8 & 6 & 0.6 & 9.2 & 0.4 & 0.51 & 0.65 & 44 \\
\hline $4 \mathrm{C}$ & 5.3 & 4.9 & 38 & 5 & 4 & 0.5 & 12.7 & 0.2 & 0.14 & 0.33 & 30 \\
\hline $5 \mathrm{C}$ & 5.1 & 4.8 & 64 & 8 & 7 & 0.4 & 9.1 & 0.3 & 0.17 & 0.47 & 27 \\
\hline \multicolumn{12}{|l|}{ Old gap } \\
\hline $\mathrm{AC}$ & $5.7 \pm 0.4 \mathrm{a}$ & $4.7 \pm 0.1 \mathrm{a}$ & 148 & 21 & 5 & 1.8 & 9.7 & 0.7 & $0.36 \pm 0.2 \mathrm{a}$ & $0.8 \pm 0.3 \mathrm{a}$ & $33 \pm 6 a$ \\
\hline $2 \mathrm{C}$ & 5.2 & 4.7 & 73 & 9 & 3 & 0.8 & 9.2 & 0.4 & 0.30 & 0.53 & 36 \\
\hline $3 \mathrm{C}$ & 5.3 & 4.8 & 17 & 7 & 2 & 0.1 & 9.5 & 0.3 & 0.10 & 0.56 & 16 \\
\hline $4 \mathrm{C}$ & 5.2 & 4.9 & 62 & 14 & 5 & 1.0 & 9.2 & 0.3 & 0.17 & 0.34 & 33 \\
\hline $5 \mathrm{C}$ & 5.3 & 5.0 & 31 & 6 & 4 & 1.2 & 9.2 & 0.2 & 0.06 & 0.41 & 13 \\
\hline $6 \mathrm{C}$ & 5.4 & 5.2 & 29 & 8 & 4 & 0.2 & 10.8 & 0.3 & 0.05 & 0.36 & 13 \\
\hline \multicolumn{12}{|l|}{ New gap } \\
\hline $\mathrm{C}$ & $5.8 \pm 0.4 \mathrm{a}$ & $4.7 \pm 0.1 \mathrm{a}$ & 72 & 8 & 6 & 1.6 & 9.9 & 0.4 & $0.27 \pm 0.2 \mathrm{a}$ & $1.4 \pm 0.9 \mathrm{a}$ & $23 \pm 4 a$ \\
\hline $2 \mathrm{C}$ & 5.3 & 4.9 & 31 & 4 & 6 & 1.0 & 9.0 & 0.2 & 0.17 & 0.31 & 35 \\
\hline $3 \mathrm{C}$ & 5.4 & 5.1 & 29 & 5 & 10 & 2.3 & 9.0 & 0.4 & 0.15 & 0.57 & 21 \\
\hline $4 \mathrm{C}$ & 5.5 & 5.1 & 45 & 8 & 28 & 9.2 & 9.0 & 0.3 & 0.17 & 0.47 & 27 \\
\hline $5 \mathrm{C}$ & 5.4 & 5.1 & 82 & 8 & 10 & 2.2 & 9.2 & 0.3 & 0.20 & 0.46 & 30 \\
\hline
\end{tabular}

Values with the same letter do not differ significantly $(p<0.05)$ between profiles to the first horizons. Values in first horizon are mean \pm standard deviation and only mean in the others horizons.

Table 4. Quantity of essential soil nutrient elements in the first $40 \mathrm{~cm}$ to the three profiles.

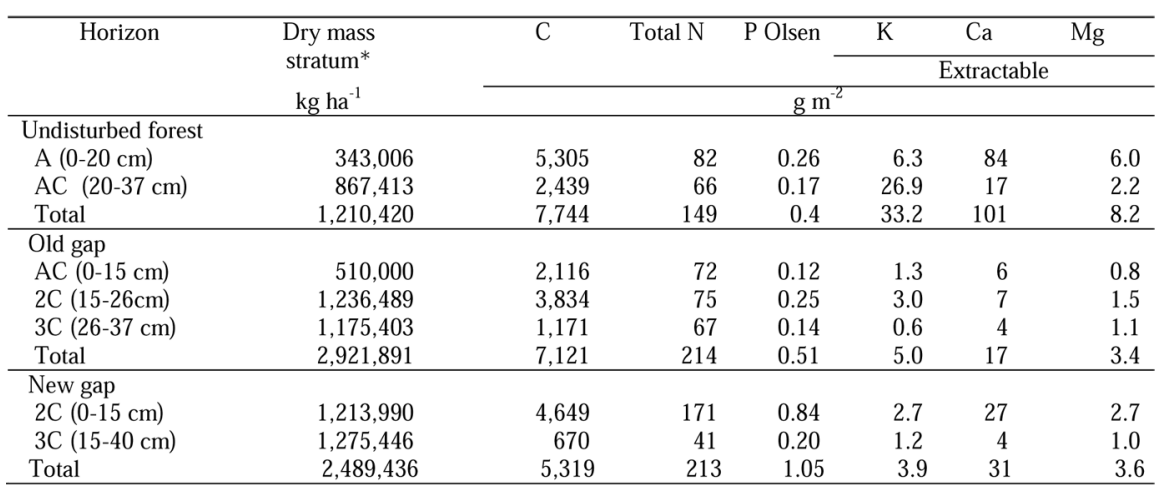

*dry mass of soil $<2 \mathrm{~mm}$. 
Therefore, the higher soil bulk density of the topsoil in the scarified gaps (Table 1) when compared to the undisturbed forest, can be explained by the removal of topsoil rather than an effect of the mechanized works, because soils with a lower content of organic matter have a higher bulk density. The total volume of pores of the superficial soil in the gaps shows lower values compared to the undisturbed forest within similar strata (Figure $2)$. It is explained by the texture change and may be partly due to compacting caused by the traffic effect of the scarifyng machine (Ellies et al. 1993; Ellies, 1999), which in sandy soils affects more the coarse porosity and increases along with higher soil moisture (Ellies and Smith, 1998), therefore it is important to choose an appropriate time (late summer or early fall) for silvicultural intervention.

These soils, in the general, have a moderate to low chemical-nutritional content. The normal trend is to find the higher content of nutrients in the $\mathrm{A}$ and $\mathrm{AC}$ horizons of the undisturbed forest $(0-40 \mathrm{~cm})$ that when removed after scarification leave a more limited soil. The $\mathrm{pH}$ is strongly acidic in most of the horizons, as expected in the forests of southern Chile (Sadzawka et al., 1995), without marked differences between situations. It must also be noted the high aluminum saturation, which may be due in part to leaching (especially calcium), because of the high rainfall in the area and the low organic matter content of the scarified soil. The low aluminum saturation in the A horizon of the undisturbed forest is associated with its high base content.

Scarification decreases the nutrient supply of topsoil, as reported by other authors (Gastadello et al., 2007; Jiménez et al., 2008), and furthermore, the high aluminum saturation can be toxic to the roots (Valle et al. 2011), creating limiting conditions in terms of fertility, so that only the species adapted to these conditions are likely to succed in their establishment (Gerding and Thiers, 2002). For this reason, both $N$. nervosa and $N$. dombeyi can adapt to post-scarifying conditions.
The soil removed from scarified areas can be considered as a loss of bioelements for the regeneration to be established, although in the long term it may become available as it accumulates in the periphery of the scarified areas and the access to it will depend on the distance between the plants and these areas. The differences in the amount of nutrients between the three situations (Table 4) are lower compared to the levels of concentration (Tables 2 and 3), because a lower content is compensated with a greater mass of soil (higher bulk density, Table 1). Although there is a decrease of bases, it is a condition that naturally occurs at establishment of Nothofagus species in this area, because of their catastrophic mode of regeneration, wich consist of establishment after coarse-scale disturbances producing whole-stand replacement patterns (Veblen and Ashton, 1978., Veblen et al., 1996). Commonly, these disturbances are caused by volcanic and tectonic activity in Andean regions, producing volcanic depositions, landslides, rockfalls, debris flows, and mudflows (Veblen et al., 1996).

The available water capacity is high in both the undisturbed forest and the scarified sectors, despite having a mostly coarse textured soil. Considering that penetration resistance is moderate $(<2 \mathrm{MPa}$, Horn and Fleige 2009), the physical characteristics of the soil allow acceptable conditions for the establishment of new regeneration, which has also been observed in the andisols of the region (Dörner et al., 2011).

It should be noted the importance of soil organic matter, which is highly linked to the base content and it also favors some physical properties, such as low levels of penetration resistance and a low bulk density (e.g. Lal and Shukla, 2004), as observed in this study and other reports on soils derived from volcanic ashes under different uses (Dörner et al., 2009; Dörner et al., 2011). This is one of the largest short-term losses for regeneration, considering that it is located mainly on the soil surface. The high amount of dry matter in litter is generated by contribution of the undisturbed forest and a slow decomposition due to cold weather (also noted in the high $\mathrm{C} / \mathrm{N}$ rate of the $\mathrm{A}$ horizon). 
Table 5. Chemical analysis of the forest litter.

\begin{tabular}{|c|c|c|c|c|c|c|c|c|c|c|c|c|}
\hline \multirow{2}{*}{$\begin{array}{l}\text { Litter } \\
\text { material }\end{array}$} & \multirow{2}{*}{$\begin{array}{c}\begin{array}{c}\text { Dry } \\
\text { mass }\end{array} \\
\mathrm{Mg} \mathrm{ha}^{-1}\end{array}$} & \multirow{2}{*}{$\begin{array}{c}\begin{array}{c}\text { Ash } \\
\text { content }\end{array} \\
\%\end{array}$} & \multicolumn{5}{|c|}{$\begin{array}{l}\text { Major essential nutrients } \\
\qquad \mathrm{g} \mathrm{m}^{-2}\end{array}$} & \multicolumn{5}{|c|}{$\begin{array}{l}\text { Minor essential nutrients } \\
\qquad \mathrm{g} \mathrm{m}^{-2}\end{array}$} \\
\hline & & & $\mathrm{N}$ & $\mathrm{P}$ & $\mathrm{K}$ & $\mathrm{Ca}$ & $\mathrm{Mg}$ & $\mathrm{Fe}$ & $\mathrm{Mn}$ & $\mathrm{Cu}$ & $\mathrm{Zn}$ & B \\
\hline $\begin{array}{l}\text { Fine } \\
(<2 \mathrm{~mm})\end{array}$ & 19 & 34 & 17.6 & 1.9 & 0.3 & 16.7 & 1.5 & 7.5 & 1.6 & 0.04 & 0.09 & 0.03 \\
\hline $\begin{array}{l}\text { Medium } \\
(2-5 \mathrm{~mm})\end{array}$ & 29 & 39 & 16.2 & 1.7 & 0.5 & 31.9 & 2.0 & 6.2 & 1.3 & 0.07 & 0.12 & 0.04 \\
\hline $\begin{array}{l}\text { Coarse } \\
(>5 \mathrm{~mm})\end{array}$ & 13 & 6 & 4.7 & 0.5 & 0.3 & 15.6 & 0.7 & 0.6 & 0.3 & 0.01 & 0.05 & 0.01 \\
\hline Total & 61 & 26 & 38.5 & 4.1 & 1.1 & 64.2 & 4.2 & 14.3 & 3.2 & 0.12 & 0.26 & 0.08 \\
\hline
\end{tabular}

Even if the removal of litter can provide easy access of seeds to the mineral soil, it is also a substantial loss of nutritive reserves. The protective role of litter is well known, protecting the soil from erosion and to maintaining a constant temperature and humidity (Hille and den Ouden, 2004). Still, soils exposed to scarification in this study showed sandy textures with high infiltration and percolation capacity, which minimize surface runoff that could cause water erosion.

The initial and after intervention conditions of soils should be considered and monitored in silvicultural management. Although intervention can facilitate the establishment of species of interest, there are changes in the physical properties (increased bulk density and penetration resistance, reduced porosity) and chemical (low organic matter content, decrease of nutrient concentration and the sum of bases; higher aluminum saturation) that indicate a decrease in the quality of soil for the establishment of new vegetation.

\section{Conclusions}

The morphology of soil in scarfied areas changes due to intervention, the magnitude depend on scarification depths. The total pore volume of topsoil decreases mainly due to a change of layer which a different texture. The nutrient supply is lower and aluminum saturation is higher in the topsoil of scarified areas. The state of the soil before and after intervention must be considered for its effects on silviculture.

\section{Acknowledgements}

The authors would like to thank the research projects Fondo de Investigación del Bosque Nativo 042/2010 (CONAF) and FONDEF D07I1034 for funding this research, and the company Forestal Neltume Carranco SA for providing the facilities. This work was realized under Master in Sciences mention Forest Resources program, from Faculty of Forest Sciences and Natural Resources, Universidad Austral de Chile.

\section{References}

Aoyama, K., Yoshida, T., Kamitani, T. 2009. An alternative of soil scarification treatment for forest restoration: effects of soil replacement. Journal of Forest Research. 14, 58-62.

CIREN (Centro de Información de Recursos Naturales, CL). 2001. Estudio Agrológico X Región. Descripciones de suelos, materiales y símbolos. Tomo I. Centro de Investigación de Recursos Naturales, Chile, 199 p. 
Donoso, C., Lara, A. 1996. Utilización de los bosques nativos en Chile: pasado, presente y futuro. In: J. Armesto, C. Villagrán, M. Arroyo (eds). Ecología de los bosques nativos de Chile. Editorial Universitaria, Santiago, Chile, pp: 363-404.

Dörner, J., Dec, D., Peng, X., Horn, R. 2009. Change of shrinkage behavior of an Andisol in southern Chile: Effects of land use and wetting/drying cycles. Soil and Tillage Research. 106, 45-53.

Dörner, J., Dec, D., Zúñiga, F., Sandoval, P., Horn, R. 2011. Effect of land use change on Andosol's pore functions and their functional resilience after mechanical and hydraulic stresses. Soil and Tillage Research. 115, 71-79.

Ellies, A., Ramírez, C., Figueroa, H. 1993. Modificaciones estructurales de un suelo sometido a distintos usos forestales. Bosque. 14(2), 25-30.

Ellies, A., Smith, R. 1998. Evaluación del efecto de cargas sobre un suelo alfisol con diferentes niveles de humedad. Agricultura Técnica. 58(3), 205-212.

Ellies, A. 1999. Efecto del manejo sobre las propiedades físicas de suelos trumaos y rojo arcillosos. Bosque. 16(2), 101-110.

Forsythe, W. 1975. Física de suelos. Manual de laboratorio. Instituto Interamericano de Ciencias Agrícolas. San José, Costa Rica, 212 p.

Gastaldello, P., Ruel, J.C., Paré, D. 2007. Microvariations in yellow birch (Betula alleghaniensis) growth conditions after patch scarification. Forest Ecology and Management. 238, 244-248.

Gerding, V., Thiers, O. 2002. Caracterización de suelos bajo bosques de Nothofagus betuloides (Mirb) Blume, en Tierra del Fuego, Chile. Revista Chilena de Historia Natural. 75, 819-833.

González-Ferrán, O. 1995. Volcanes de Chile. Instituto Geográfico Militar, Santiago, Chile, 640 p.
Hartge, K., Horn, R. 1992. Die physikalische Untersuchung von Böden. Ferdinand Enke Verlag, Stuttgart, Germany, 177 p.

Henderson, C., Levett, A., Lisle, D. 1988. The effects of soil water content and bulk density on the compactibility and soil penetration resistance of some Western Australian sandy soils. Australian Journal of Soil Research. 26, 391-400.

Hille M., den Ouden, J. 2004. Improved recruitment and early growth of Scots pine (Pinus sylvestris L.) seedlings after fire and soil scarification. European Journal of Forest Research. 123, 213218

Hope, G. 2007. Changes in soil properties, tree growth, and nutrition over a period of 10 years after stump removal and scarification on moderately coarse soils in interior British Columbia. Forest Ecology and Management. 242, 625-635.

Horn, R. Fleige, H. 2009. Risk assessment of subsoil compaction for arable soils in Northwest Germany at farm scale. Soil and Tillage Research. 102, 201208.

INIA (Instituto Nacional de Investigaciones Agropecuarias, CL). 1989. Mapa agroclimático de Chile. Ministerio de Agricultura, Santiago, Chile, $221 \mathrm{p}$.

Jiménez, A., Stromberger, M., Shepperd, W. 2008. Soil scarification and wildfire interactions and effects on microbial communities and carbon. Soil Science Society of America Journal. 72, 111-118.

Lal, R., Shukla, M. 2004. Principles of Soil Physics. Marcel Dekker, New York, 688 p.

Ministerio de Agricultura. 2008. Ley No 20.283. Ley sobre recuperación del bosque nativo y fomento forestal. Dictada el 11 de julio de 2008; publicada en el diario oficial el 30 de julio de 2008. 
Nyland, R. 2002. Silviculture concepts and applications. McGraw-Hill, New York, USA, 631 p.

Resco de Dios, V., Yoshida, T., Iga, Y. 2005. Effects of topsoil removal by soil-scarification on regeneration dynamics of mixed forests in Hokkaido, Northern Japan. Forest Ecology and Management. 215, 138-148.

Röhrig, E,. Bartsch, N,. Lüpke, B. 2006. Waldbau auf ökologischer Grundlage. Ulmer, Stuttgart, 479 p.

Sadzawka, A., Peralta, M., Ibarra, M., Peralta, J., Fuentes, J. 1995. Características químicas de los suelos forestales chilenos. Bosque. 16(1), 9-28.

Sadzawka, A., Carrasco, M., Grez, R., Mora, M., Flores, H., Neaman, A. 2006. Métodos de análisis recomendados para los suelos de Chile. Instituto de Investigaciones Agropecuarias, Santiago, Chile, 164 p.

Sadzawka, A., Carrasco, M., Demanet, R., Flores, H., Grez, R., Mora, M., Neaman, A. 2007. Métodos de análisis de tejidos vegetales. Segunda Edición. Instituto de investigaciones Agropecuarias, Santiago, Chile, $140 \mathrm{p}$.

Schlatter, J., Grez, R., Gerding, V. 2003. Manual para el reconocimiento de suelos. Universidad Austral de Chile, Valdivia, Chile, 114 p.
Thiers, O. 2004. Roble (Nothofagus obliqua)Sekundarwälder in Zentral- und Südchile: Bestimmung der für die Bestandesproduktivität wichtigen Standortsfaktoren. Freiburger Bodenkundliche Abhandlungen $\mathrm{N}^{\circ} 42.170 \mathrm{p}$.

Valle, S., Pinochet, D., Calderini, DF. 2011. Uptake, partitioning and use efficiency of N, P, K, Ca and $\mathrm{Al}$ by wheat $\mathrm{Al}$-sensitive and Al-tolerant cultivars under a wide range of soil $\mathrm{Al}$ concentrations. Field Crops Research. 121, 392-400.

Veblen, T., Ashton, D. 1978. Catastrophic influences on the vegetation of the Valdivian Andes. Plant Ecology. 36, 149-167.

Veblen, T., Donoso, C., Kitzberger, T., Rebertus, A. 1996. Ecology of Southern Chilean and Argentinean Nothofagus forest. In: T. Veblen, R. Hall, J. Read (eds). The Ecology and Biogeography of Nothofagus forest. Yale University Press, New Haven, pp: 293-353.

Zaczek, J. 2002. Composition, diversity, and height of tree regeneration, 3 years after soil-scarification in a mixed-oak shelterwood. Forest Ecology and Management. 163, 205-215.

Zar, J. 2010. Biostatistical Analysis. 5th Ed. Upper Saddle River, NJ, USA, Prentice Hall, 960 p. 